\title{
2: 87000696-86954120
}

National Cancer Institute

\section{Source}

National Cancer Institute. 2:87000696-86954120. NCI Thesaurus. Code C41914.

Physical location of CD8B1_Gene 